Voting with the Crowd:

Do Single Issues Drive Partisanship?

Martin B. Schmidt
College of William and Mary

College of William and Mary

Department of Economics

Working Paper Number 57

September 2007 
COLLEGE OF WILLIAM AND MARY

DEPARTMENT OF ECONOMICS

WORKING PAPER \# 57

September 2007

\title{
Voting with the Crowd: Do Single Issues Drive Partisanship?
}

\begin{abstract}
We examine whether survey data supports the anecdotal evidence which suggests that group association impacts the individual's stated beliefs. Specifically, we examine whether a rise in the relative importance of a single issue, i.e., national security, blurs the traditional importance of socio-economic variables in determining an electorate's political party association. Further we examine whether such blurring occurs across the responses to questions outside the scope of this single issue. We find that in the aftermath of the terrorist attacks on September 11th, 2001, the relative importance of national security rose in United States' electorate and reduced the relative importance of socio-economic variables in determining the electorate's political association and for both security and non-security issues.
\end{abstract}

JEL Codes: E41; E52; C32

Keywords: Elections, Voting Preferences, Group Preferences, Conformity

Martin B. Schmidt

Department of Economics

College of William and Mary

Williamsburg, VA 23187-8795

mbschm@wm.edu 


\section{Introduction}

A recent Time/ABC News/Stanford University opinion poll found that $46 \%$ of self-described

Democrats and $45 \%$ of self-described Independents are extremely or very sure that global warming is occurring. These contrast with the responses of self-described Republicans where only $26 \%$ were extremely or very sure. ${ }^{1}$ A similar divide was found in a recent Fox News Opinion Poll where respondents were asked whether the global warming was occurring, again Democrats (91\%) and Independents (84\%) where more likely than Republicans (61\%) to respond that it was. ${ }^{2}$

Even given the belief in its occurrence, the partisan divide remained. When one considers who is responsible for global warming, slightly more than half of Democrats - $52 \%$ believe human behavior is the cause of global warming as compared to roughly a third of Republicans - 30\%. Interestingly one thing Democrats and Republican respondents did seem to agree upon was the course of corrective action. Both parties were in favor of providing tax incentives to encourage firms to become eco-friendly, with $75 \%$ of Republicans and $70 \%$ of Democrats in favor of the idea.

This anecdotal evidence raises a question: why would political identification affect the belief in or the cause of global warming? While one might suspect that ideology would cause one to be suspect (or be confident) of the government's ability to correct the possible externality, its existence or cause would seem outside the auspices of party identification based on ideology. ${ }^{3}$ More generally, one may ask what role group association plays in voters' responses to survey

\footnotetext{
${ }^{1}$ http://abcnews.go.com/images/Politics/1009a1GlobalWarming.pdf

${ }^{2}$ http://www.foxnews.com/projects/pdf/020207\_global \_warming \_web.pdf

${ }^{3}$ Consider, for example, the degree of pollution in most large metropolitan cities. While political party and ideology may indicate whether a respondent would support a particular government regulation or solution, it would seem difficult to deny it's existence - one needs only to look up to the heavens!
} 
questions. It is possible that, for a portion of survey respondents' responses, the individual is not revealing their true beliefs but are rather expressing the party line. ${ }^{4}$

The issue is of more than causal interest. If, for example, an exogenous shock causes members to switch from one party to the other, the choices made in a democratic society may be suboptimal, e.g. Campbell (1994). While the switching on a single issue may produce the society's optimal with respect to this choice, it will increase the likelihood that a whole subset of other issues will change - even those that may be in a minority position.

The present paper investigates the following question: does group association change the individual stated views? ${ }^{5}$ For example, suppose an individual changes party affiliation based on a rise in the relative importance of a single issue - the terrorist attacks which occurred on September 11 $1^{\text {th }}, 2001$ in the United States appear to have increased the importance of security relative to other issues. Anecdotal evidence suggests that this produced, on the margin, a change in the makeup of party identification, i.e., we should see movement to the party which represents this concern more closely. If so, the question is whether once the individual has 'switched sides' does he/her change their positions on all or a subset of less important issues?

The issue is similar but separate from that addressed in Glaeser et al (2005). The issue there dealt with why a political candidate chooses the party line. Here the issue is why the voter chooses the party line. In order to investigate this question, we begin by investigating the factors which influence party identification. We follow Glaeser et al (2005) and model party identification on the basis of socio and economic demographic variables. We then examine how the relative importance of these factors changed as an outgrowth of the 9/11 terrorist attacks. We

\footnotetext{
${ }^{4}$ An alternative is that given heterogeneous information, the individual is relying on others - presumably those who the individual associates with - to inform her of her opinion.

5 The role of group or social interactions in other contexts has been addressed elsewhere. For example, Glaeser Sacerdote and Scheinkman (1996) investigate its importance in determining the decision to commit a crime, Binder and Pesaran (2001) and House and Ozdenoren (2006) examine its role in consumption, and Akerlof, Katz and Yellen (1996) incorporates social interactions to investigate out-of-wedlock births.
} 
compare individual's responses to both security and non-security questions and describe how these changed in the post-9/11 world. Finally we borrow heavily from literature on cognitive dissonance (Festinger (1957) and Akerlof and Dickens (1982)) and conformity (e.g. Akerlof and Kranton (2000), Akerlof (1997), Jones (1984), and Bernheim (1994)) to provide a brief foundation.

\section{A Model of Party Identification}

Rules of thumb provided by the news media and pollsters suggest that group membership plays a significant role in determining which political party an individual associates themselves with. Group membership may be given by characteristics given at birth, as is the case of age, gender, race and perhaps religion. Group membership may also be an outcome of achievement as in the case with education and income. ${ }^{6}$ Finally, group membership may also be driven by choice variables as is the case with marital status, union membership, the regularity of church attendance, political knowledge, etc.

In order to formally model party identification we follow Glaeser et al (2005) and hypothesize the following rudimentary model:

$$
\begin{aligned}
P_{i} & =\beta_{0}+\beta_{1} * A_{i}+\beta_{2} * G_{i}+\beta_{3} * R+\beta_{4} * E_{i}+\beta_{5} * Y_{i}+\beta_{6} * Y_{i}^{2}+\sum_{j=7}^{9} \beta_{j} \operatorname{Re} g_{i}+\sum_{k=10}^{13} \beta_{k} \operatorname{Re} l_{i} \\
& +\beta_{14} * H M_{i}+\beta_{15} * H O_{i}+\beta_{16} * U_{i}+\beta_{17} * M_{i}+\sum_{l=18}^{19} \beta_{l} * K_{i}+\varepsilon_{i}
\end{aligned}
$$

where $\boldsymbol{P}$ represents individual (i)'s party association. The respondent's age, gender and race groups are captured through $A, G$, and $R$, respectively. His/Her educational attainment and income levels are captured through the variables $E$ and $\boldsymbol{Y}$, and $\boldsymbol{Y}^{2}$, where the latter is included to capture diminishing returns to income with respect to party association.

\footnotetext{
${ }^{6}$ Obviously, in the present case achievement has no normative implication. Rather, it is expressed as the outcome of a game played by individuals.
} 
We also include the respondent's Census region, $\boldsymbol{R e g}$, and religious preference, $\boldsymbol{R e l}$. As stated religion fails to highlight the relative importance of religion to the individual we included the regularity of church attendance as one of the religion variables. $H M$ and $H O$ represent dummy variables which capture whether the respondent was a homemaker and whether the respondent owned their home, respectively. Union membership or close association to a union member is captured with $U$ and marital status is captured in $M$. Finally we include two variables which capture the respondent's level of political knowledge, $K$.

We next turn to estimating the above equation using the American National Election Survey data.

\section{September 11 ${ }^{\text {th }}, 2001$ and the American National Election Survey.}

In the aftermath of the September 11 ${ }^{\text {th }}, 2001$ terrorist attacks, all public opinion polls recorded a very large swing in the public's view of the importance of national security. Anecdotally one might remember the comedian Dennis Miller who stated that: ${ }^{7}$

"Nine-11 changed me," he said. "I'm shocked that it didn't change the whole country, frankly."

Miller went on to state that the attacks were largely responsible for his transformation into advocate for Republicans after years of working for Democrats. More formally, one may consider a November 2002 Greenberg, Quinlan, Rosner Research Inc poll which found that: 8

“... 57 percent of voters say that Bush's performance on "foreign affairs and international issues" had more of an influence on their vote than his performance on "the economy, tax cuts, and corporate corruption. (p. 2)"

Both of these suggest that national security had a significant impact on the United States' electorate following the events of September $11^{\text {th }}, 2001$. While such rhetoric may motivate the

\footnotetext{
${ }^{7}$ http://www.cnn.com/2004/SHOWBIZ/TV/01/26/tv.dennismiller.ap/

${ }^{8}$ http://www.gqrr.com/articles/1266/856_VVAF\%20Post-Election\%202002.pdf
} 
issue, a more formal approach is required.

a) The American National Election Survey. In order to examine the impact that 9/11 had on voters' allegiances we turn to survey data from the American National Election Committee. ${ }^{9}$ The study has been conducted on a bi-annual basis since 1948. As stated on it's website, the mission of the ANES is to: ${ }^{10}$

“... inform explanations of election outcomes by providing data that support rich hypothesis testing, maximize methodological excellence, measure many variables, and promote comparisons across people, contexts, and time."

For our purpose the survey provides responses to whether the individual respondent associates themselves with the Republican Party, Democratic Party or with neither, i.e., they consider themselves an Independent. Moreover, the survey provides most of the group membership variables which are of interest. Finally, the data is particularly attractive as the question we ask has a time series component and the ANES data provides a time series of responses.

In the analysis that follows we incorporate only the 2000 and 2004 responses. The choice of these two periods represents a compromise of sort on our part. As the terrorist attacks occurred in 2001, one might have liked to compare the 2000 and 2002 surveys. However there are several difficulties which limit our ability to do this. The first, and perhaps most significant, is that the 2002 survey did not ask for, one of the more theoretically important variables, the respondent's income level. A second is that election of 2002 was a mid-term election and comparing it to 2000 - a Presidential election year - may be problematic. Mid-term elections generally have much lower turnout, much lower level of involvement and much lower level of interest. It would be difficult to model this dimension. Finally, the comparison to 2004 may yield a sense of the staying power of the group association effect, i.e., does it have a lasting effect?

\footnotetext{
9 The cumulative data file was obtained from the ANES website http://www.electionstudies.org/studypages/cdf/cdf.htm

${ }^{10}$ http://www.electionstudies.org/
} 
Table I reports the result of estimating the above equation incorporating the ANES data.

The dependent variable in the equation is a dummy variable which returns a value of unity if the respondent replied he/she was a Republican and a value of (0) if the response was Democrat or Independent. ${ }^{11}$ The other variables are described more fully in the accompanying appendix. Also, given that the dependent variable is binary, we make use of the probit model to estimate the equation. Finally, as a significant amount of heteroskedasticity existed in all of the estimation that followed, we report robust standard errors in each of the following tables.

In general, results for the year 2000 (Column 1) subset provide support for the group associations described above, i.e., equation (1). Specifically, both the gender and race variables suggest that white males are significantly more likely to affiliate themselves with the Republican Party than are females and non-whites. The results also suggest that respondents which had attained higher levels of education and income where more likely to associate themselves with the Republican Party.12

Religion and marital status also appear to play a significant role in party identification. For example, consider that those respondents who described themselves of the Jewish religion where more likely to consider themselves Democrats and the more regularly the respondent went to church the more likely they were to associate themselves with the Republican Party. While not specifically a religion variable, married respondents where significantly more likely to tie themselves to the Republican Party than non-married respondents.

A few additional responses existed. Respondents who were members of a union or who had someone in the household who were members of a union were less likely to belong to the

\footnotetext{
11 The results are generally robust if one includes the Independent responses with the Republican observations.

12 The income variables indicates that respondents whose income placed them in the top 5\% where more likely to associate themselves with the Republican Party, while the other 95\% where less likely.
} 
Republican Party. Homemakers and those who owned their own home were $20 \%$ more likely to join the Republican Party than their counterparts. Finally, a respondent who was deemed to have a high level of political knowledge was found to be less likely to belong to the Democratic Party.

All of this suggests that the most Republican respondent in 2000 was a 'church-going, high income, educated, politically-informed, homeowner, non-union, white male homemaker.'

While most of these variables continue to be significant for respondents in 2004, a number of these variables experienced a decline in their relative importance, many on the order of $25-50 \%$. Specifically consider the impact of religion. Both Jewish respondents and respondents who attended church less regularly were less likely to belong to the Democratic Party, the Jewish coefficient by nearly $50 \%$. For our analysis, the important observation is that the distinction between Republican Party and Democratic Party members became less clear at least along religious lines. A similar blurring of the socio-economic Party lines occurred for marital status, union membership and political knowledge, income, education and home ownership. The latter three, which were all significant in determining party association in 2000, became insignificant in 2004.

In contrast, the likelihood of joining the Republican Party increased for middle-aged, white males and for homemakers. Specifically, white respondents where nearly $15 \%$ more likely to associate themselves with the Republican Party in 2004 as compared to 2000. Both the gender variable and homemakers experienced much larger increases. Finally, the age variable respondents between the ages of 30-60 - was insignificant for the 2000 respondents; it however doubles in size and becomes significant for 2004.

One might argue that the events and aftermath of September 11th, 2001 had very different affects on different socio-economic groups. Finally, the bottom row reports the results of 
performing a Chow test on the linear version of equation (1). The test suggests that a significant break occurred between the observations from 2000 and the observations and $2004 .^{13}$

b) Age, Gender, Race and Homemakers. The results presented in Table I indicated that while a number of socio-economic demographics became less important in determining political party affiliation, age, gender, race and homemakers became more important. In order to examine whether the decision to join - at least rhetorically - the Republican Party caused these individuals to become more Republican, we turn to the responses to several other questions reported in the $2000 \& 2004$ ANES surveys.

Table II and Table III report the results of applying the earlier methodology on party affiliation to two questions which deal with national security issues. Specifically, Table II examines the socio-economic determinants of responses to the question of 'whether the United States is in a stronger position today than a year ago.' Table III reports impact these variables have on the respondent's stated belief on the correctness of the level of military spending.

In general, all four of these variables, age, gender, race and homemaker, return the same adjustment between 2000 and 2004. Specifically, Table II reports a large decline in the estimated coefficients for nearly all of these variables. The age and race variables, for example, become negative and significant as compared to 2000 - a result indicative of white middle-aged respondents being significantly more likely to believe the Untied States was in a stronger position today than their counterparts were. Given the Government's response to the events of September $11^{\text {th }}, 2001$, these individuals appear to be more likely to believe that the response was appropriate. Also, while not significant, both the gender and homemaker variables experienced a similar movement as their coefficients became more negative in 2004.

\footnotetext{
${ }^{13}$ It should be noted that this result is unlikely an outgrowth of a skewed distribution of middle-aged white males in the 2004 surveys. In both surveys, the percentage of respondents who reported they were Republicans was roughly $40 \%$.
} 
A possible explanation for this response revolves around the application of cognitive dissonance to group association. In this context, cognitive dissonance would suggest that once an individual joins a club, the individual has the incentive to adjust their view of the club's benefit or performance to make one feel better. We will discuss this issue more at length in the next section.

Table III provides the impact of these variables to the responses to the desirability of increased spending on the military. As with the previous two questions the estimates from 2000 to 2004 yields similar movements in the coefficients of age, gender, race and homemakers. Specifically, white males were much more likely to desire increased military expenditures in 2004 than in 2000. In addition while not significant both the age and homemaker coefficients become more positive over two periods.

Table I, III, III suggest that, against the backdrop of September 11 ${ }^{\text {th }}$ 2001, middle-aged, white males and homemakers realigned themselves with the Republican Party between 2000 and 2004 and that associated with this realignment is an increased desire for national security and a belief in the improved standing of the United States.

c) Outside the auspices of national security. As framed earlier, the question of the present piece is whether once an individual realigns oneself with a particular group do they choose to conform, i.e., to adopt the group's views. In order to more closely examine this question, we now turn to four additional questions which where asked in the 2000 and 2004 ANES surveys. These questions are all outside the auspices of national security and therefore one might expect that these questions should produce results at variance with those presented above.

Two of the questions specifically address non-military government expenditures. The two other questions address government involvement or regulation of market and personal 
rights. All of these typically divide along political lines and therefore provide a test for the adoption of group preferences.

Table IV reports the socio-economic determinants of the preference for welfare spending. Along similar lines, Table $\mathbf{V}$ reports the determinants of the preference for public education spending. Both of the tables suggest that middle-aged, white males and homemakers reduced their preference for both of these in the aftermath of 9/11. Specifically, for both questions each of these variables returns a positive coefficient indicating a preference to reduce both expenditures on welfare and public education expenditures. Moreover for the question of increased public education expenditures, the coefficients for gender and race rise by an average of nearly $50 \%$ for 2004 . Both the middle-age and homemaker variables are insignificant but both coefficients' signs change from negative to positive between 2000 and 2004. All of this is quite similar to the findings in Tables I-III.

Now one might argue that the movements in Table IV and V reflect recognition by individual respondents that government expenditures are not infinite rather than some form of conformity on the part of respondents. In which case, the priority of military expenditures in the wake of 9/11 requires that other government expenditures be decreased.

We, therefore now turn to two non-spending, non-national security questions. Specifically, Table VI examines the question of a woman's right to choose and Table VII examines the question of whether the respondent supports affirmative action. Similar to the results presented in the previous tables, an examination of Table VI and Table VII finds a precipitous decline in support for both of these positions. Specifically, both the middle-aged and homemakers became less supportive of abortion rights in 2004; this is particularly true for homemakers where the coefficient nearly doubled between the two periods. Support for affirmative action declined significantly among those between the ages of 30 and 60, i.e., Table 
VII reports that for 2000 respondents, the age variable was insignificant.

In the end, the results provide support for a degree of group association in respondents' stated opinions. The post-9/11 period experienced a movement toward more traditional Republican positions. This was true whether the questions that respondents were asked dealt with party affiliation, national security or government involvement in market and personal choice. All of which suggests that to some degree, the action of the individual - the movement to another group - drives preferences and beliefs.

d) Cognitive Dissonance and Conformity. While other explanations may exist, two of the more likely explanations for the above results are (1) the theory of cognitive dissonance (Festinger (1957)) and (2) the theory of conformity (Bernheim (1994)). While the two theories are highly correlated, they do differ significantly; cognitive dissonance causes individuals to change behavior as a result of internal pressure while conformity causes individuals to change their behavior as a result of external pressure. Specifically, cognitive dissonance occurs where an individual desires to rationalize actions that differ from their own preferences. Here the issue the need for the individual to maintain an internal balance. In contrast, conformity occurs where the individual values group membership. Here, the issue the need to 'fit in.'

In the present context, once an individual has realigned themselves with a competing political party due to the prevalence of his/her single issue, the individual is faced with supporting candidates and associating with others who do not share their preferences on secondary issues. The cognitive dissonance revolves around how the individual deals with this tacit support for opposing positions. For some, the least costly adjustment may come about by adopting, at least rhetorically, the group's opinions on secondary issues, even if these are contrary to their true beliefs.

Conformity on the other hand is a desire on the part of the individual to fit in, i.e., to 
conform, with the group. However, neither conformity nor cognitive dissonance needs to be universal. Conformity, for example, is an outgrowth of the relative strength of the individual's desire for popularity and esteem which may vary across individuals and contexts. Bernheim (1994) presents a model where an individual faces a utility function that is a weighted sum of two components, intrinsic utility and esteem. While the individual's intrinsic utility is driven by the individual's actions, their esteem is driven by what type others believe the individual to be.

Conformity, therefore, arises when agents are sufficiently motivated by esteem to sacrifice utility in order to fit in with the societal norm. Whether or not conformity arises depends on the relative weight given to esteem - if esteem has low weight then conformity does not result while the larger is the weight given to esteem the stronger is the conformity.

One may think of the present results in similar terms, where the individual supports the group which has the same position as the individual on their most important issue. Once the decision to join the group is made, the individual may choose to state opinions which are contrary to the individual's true beliefs in an effort to 'fit in.'

\section{Conclusion}

The present paper examined the impact of the events of September 11th, 2001 on political party association. Using American National Election Survey and self-reported socio-economic demographic indicators, we found that a number of the traditional relationships between these variables and party association had blurred. For some, however, the lines became starker. Specifically, middle-age, white males and homemakers became increasingly more 'Republican' in the post-2000 period

A second finding was that the shift in party association for this group was generally coupled with a shift in their stated opinions on a number of issues. This group has a tendency to 
believe that the United States was in a stronger position than their counterparts with this difference becoming larger in 2004. In addition, this group desired more government spending on national security and less on welfare and public education. Again this difference became larger in 2004. Finally, the group saw decreased support for a woman's right to choose and for affirmative action. All in all, the group became more "Republican' and less 'Democrats.' 


\section{References}

Akerlof, George A., “Social Distance and Social Decisions,” Econometrica, 1997, 65, 1005 - 1027. and William T. Dickens., “The Economic Consequences of Cognitive Dissonance," American Economic Review, 1982, 72, 307-319.

and Rachel E. Kranton, “Economics and Identity,” Quarterly Journal of Economics, 2000, $115,715-753$.

, Michael Katz, and Janet Yellen (1996) "An Analysis of Out-of-Wedlock Childbearing in the United States," Quarterly Journal of Economics, 1996, 111, 277-318.

Bernheim, B. Douglas, “A Theory of Conformity," Journal of Political Economy, 1994, 102, 841877.

Binder, Michael and M. Hashem Pesaran. "Life-cycle consumption under social Interactions." Journal of Economic Dynamics and Control, 2001, 25, 35-83.

Campbell, Colin M., "Large Electorates and Decisive Minorities," Journal of Political Economy, 1999, 107, 1199-1217.

Festinger, Leon. A Theory of Cognitive Dissonance. Stanford, CA: Stanford University Press, 1957.

Glaeser, Edward L., Bruce Sacerdote and Jos'e A. Scheinkman, "Crime and Social Interactions," Quarterly Journal of Economics, 1996, 111, 508-548.

Giacomo A. M. Ponsetto, and Jesse M. Shapiro, "Strategic Extremism: Why Republicans and Democrats Divide on Religious Values," Quarterly Journal of Economics, 2005, 120 (4), 12831330.

House, Christopher and Emre Ozdemoren "Durable Goods and Conformity. " NBER Working Paper 12028, 2006.

Jones, Stephen R. G., The Economics of Conformism, New York, USA: Basil Blackwell, 1984. 
Appendix: American National Election Survey Questions

\section{Dependent Variables:}

VCF0303 - Respondent's Political Party - (1) Republican, (0) Other;

VCF9045 - Respondent's Opinion: Is Position of the U.S. Weaker/Stronger than one-year ago - (1) Weaker, (0) Otherwise;

VCF0843 - Respondent's Placement: Defense Spending Scale - (1) Increase, (2) Other.

VCF0894 - Respondent's Opinion: Federal Spending- Welfare Programs - (1) Decreased or cut altogether, (0) Other;

VCF0890 - Respondent's Opinion: Federal Spending- Public Schools - (1) Decreased or cut altogether, (0) Other;

VCF0838 - Respondent's Opinion: By Law, When Should Abortion Be Allowed - (1) Always, (0) limited or never.

VCF0867 - Respondent's Opinion: Do you support Affirmative Action - (1) No, (0) Other.

Independent Variables:

VCF0101 - Respondent's Age

VCF0104 - Respondent's Gender - (1) Male, (0) Female;

VCF0106 - Respondent's Race - (1) White, (0) other;

VCF0110 - Respondent's Education - (1) Grade school or less (0-8) grades, (2) High school (12

grades or fewer, including non-college training if applicable) (3) Some college

(13 grades or more but no degree, (4) College or advanced degree;

VCF0114 - Respondent's Income Percentile - (1) 0 to 16 percentile, (2)17 to 33 percentile, (3)

34 to 67 percentile, (4) 68 to 95 percentile, (5) 96 to 100 percentile;

VCF0113 - Does the Respondent live in the South - (1) South, (0) Other;

VCF0112 - Respondent's Census region.

VCF0116 - Homemaker - (1) Homemaker, (0) Other;

VCF0127b - Who Belongs to Union - (0) No one, (1) Respondent only, (2) Someone other than Respondent only (3) Respondent and someone other than Respondent;

VCF0128 - Religion of Respondent (Major Groups) - (1) Protestant, (2) Catholic [Roman Catholic], (3) Jewish, (4) Other and none (also includes DK preference)

VCF0130 - Church Attendance - (1) Every week, (2) Almost every week, (3) Once or twice a month, (4) A few times a year, (5) Never;

VCF0146 - (Do you/ Does your family) own your own home, pay rent or what? - (1) Yes, (0) Otherwise;

VCF0147 - Marital Status - (1) Married and living with spouse, (2) Never married, (3) Divorced, (4) Separated, (5) Widowed, (7) Partners;

VCF0050a - Respondent's general level of information about politics and public Affairs (Pre Interviewer Observation) seemed - (1) Very high, (2) Fairly high,

(3) Average, (4) Fairly low, (5) Very low. 
Table I: Determinants of Party Affiliation

\begin{tabular}{|c|c|c|}
\hline \multirow{2}{*}{$\begin{array}{l}\text { Dependent Variable: Party Identification - } \\
\text { (VCF0303) }\end{array}$} & \multicolumn{2}{|c|}{ Year } \\
\hline & 2000 & 2004 \\
\hline (1) Middle age - (VCF0101) & $\begin{array}{c}0.078 \\
(0.067)\end{array}$ & $\begin{array}{l}0.174^{* *} \\
(0.083)\end{array}$ \\
\hline (2) Gender - (VCF0104) & $\begin{array}{c}0.211^{* * *} \\
(0.070)\end{array}$ & $\begin{array}{c}0.243^{* * *} \\
(0.083)\end{array}$ \\
\hline (3) Race - (VCF0106) & $\begin{array}{c}0.582^{* * *} \\
(0.084)\end{array}$ & $\begin{array}{c}0.778^{* * *} \\
(0.096)\end{array}$ \\
\hline (4) Education - (VCF0110) & $\begin{array}{l}0.101^{* *} \\
(0.043)\end{array}$ & $\begin{array}{c}0.044 \\
(0.052)\end{array}$ \\
\hline (5) Income - (VCF0114) & $\begin{array}{c}-0.118^{*} \\
0.074\end{array}$ & $\begin{array}{l}-0.043 \\
(0.089)\end{array}$ \\
\hline (6) Income ${ }^{2}-\left(V C F 0114^{*} V C F 0114\right)$ & $\begin{array}{l}0.028^{*} \\
(0.016)\end{array}$ & $\begin{array}{c}0.018 \\
(0.018) \\
\end{array}$ \\
\hline (7) South - (VCF0113) & $\begin{array}{c}0.083 \\
(0.086)\end{array}$ & $\begin{array}{c}0.153 \\
(0.104)\end{array}$ \\
\hline (8) Northeast - (VCF0112) & $\begin{array}{l}-0.008 \\
(0.103)\end{array}$ & $\begin{array}{l}0.040 \\
(0.121)\end{array}$ \\
\hline (9) West - (VCF0112) & $\begin{array}{c}0.127 \\
(0.098)\end{array}$ & $\begin{array}{c}0.135 \\
(0.113)\end{array}$ \\
\hline (10) Protestant - (VCF0128) & $\begin{array}{c}0.163 \\
(0.108)\end{array}$ & $\begin{array}{c}0.202 \\
(0.127)\end{array}$ \\
\hline (11) Catholic - (VCF0128) & $\begin{array}{c}0.099 \\
(0.117)\end{array}$ & $\begin{array}{l}-0.039 \\
(0.136)\end{array}$ \\
\hline (12) Jewish - (VCF0128) & $\begin{array}{c}-1.044^{* * *} \\
(0.270)\end{array}$ & $\begin{array}{c}-0.597^{* *} \\
(0.262)\end{array}$ \\
\hline (13) Church Attendance - (VCF0130) & $\begin{array}{c}-0.067^{* * *} \\
(0.023)\end{array}$ & $\begin{array}{c}-0.059^{* *} \\
(0.027)\end{array}$ \\
\hline (14) Homemaker - (VCF0116) & $\begin{array}{l}0.213^{*} \\
(0.125)\end{array}$ & $\begin{array}{c}0.421^{* * *} \\
(0.158)\end{array}$ \\
\hline (15) Homeownership - (VCF0146) & $\begin{array}{c}0.218^{* * *} \\
(0.076)\end{array}$ & $\begin{array}{l}0.047 \\
(0.095)\end{array}$ \\
\hline (16) Union - (VCF0127) & $\begin{array}{c}-0.415^{* * *} \\
(0.101)\end{array}$ & $\begin{array}{c}-0.386^{* * *} \\
(0.108)\end{array}$ \\
\hline (17) Marital Status - (VCF0147) & $\begin{array}{l}-0.080^{* * *} \\
(0.023)\end{array}$ & $\begin{array}{c}-0.066^{* *} \\
(0.031)\end{array}$ \\
\hline $\begin{array}{l}\text { (18) Political Knowledge (Pre) - } \\
\text { (VCF0050a) }\end{array}$ & $\begin{array}{c}-0.087^{* *} \\
(0.035)\end{array}$ & $\begin{array}{c}-0.059^{* *} \\
(0.028)\end{array}$ \\
\hline $\begin{array}{l}\text { (19) Political Knowledge (Post) - } \\
\text { (VCF0050b) }\end{array}$ & $\begin{array}{l}-0.001 \\
(0.025)\end{array}$ & $\begin{array}{l}-0.020 \\
(0.029)\end{array}$ \\
\hline (0) Year Dummy & $\begin{array}{c}-0.760^{* * *} \\
(0.280)\end{array}$ & $\begin{array}{c}-0.818^{* * *} \\
(0.318)\end{array}$ \\
\hline Chow Forecast test & $\log 1$ & 23.188 \\
\hline
\end{tabular}

Note: Data comes from the American Election Survey Study - 1948-2004. The present only incorporates data from the 2000 \& 2004 surveys. Party identification is produced from VCF0303 and is a dummy variable which takes the value of unity if the respondent identifies oneself as a Republican and a value of zero otherwise. VCF0101 captures the respondent age. VCF0104 is a dummy variable which takes the value of one if the respondent is MALE and zero otherwise. VCF0106 is a dummy variable which takes the value of one if the respondent is WHITE and zero otherwise. VCF0110 is a categorical dummy variable which takes values from 1-4, where higher values representing higher Educational Attainment. VCF0113 is a dummy variable which takes the value of one if the respondent resides in the South and zero otherwise. VCF0114 is a categorical dummy variable which takes values from 1-7, where higher values represent higher Income earnings. VCF0116 is a categorical dummy variable which is split into 4 groups which take a value of one if the respondent is Homemaker and zero otherwise. VCF0127b is a categorical dummy variable which takes the value of 1-4 with higher values representing greater family Union Membership. VCF0130 is a categorical dummy 
variable which takes the value of 1-4 with higher values representing greater family Church attendance. VCF0146 is a dummy variable which takes the value of unity if the respondent owns their home and a value of zero otherwise. 
Table II: Is the United States in Stronger Today?

\begin{tabular}{|c|c|c|}
\hline \multirow{2}{*}{$\begin{array}{c}\text { Dependent Variable: US Position - } \\
\text { (VCF9045) }\end{array}$} & \multicolumn{2}{|c|}{ Year } \\
\hline & 2000 & 2004 \\
\hline (1) Middle age - (VCF0101) & $\begin{array}{c}0.081 \\
(0.068)\end{array}$ & $\begin{array}{l}-0.137^{*} \\
(0.080)\end{array}$ \\
\hline (2) Gender - (VCF0104) & $\begin{array}{c}0.077 \\
(0.071)\end{array}$ & $\begin{array}{l}-0.074 \\
(0.080)\end{array}$ \\
\hline (3) Race - (VCF0106) & $\begin{array}{c}0.285^{* * *} \\
(0.087)\end{array}$ & $\begin{array}{l}-0.206^{* *} \\
(0.088)\end{array}$ \\
\hline (4) Education - (VCF0110) & $\begin{array}{l}-0.04 \\
(0.044)\end{array}$ & $\begin{array}{c}0.233^{* * *} \\
(0.051)\end{array}$ \\
\hline (5) Income - (VCF0114) & $\begin{array}{c}0.065 \\
(0.076)\end{array}$ & $\begin{array}{l}0.168^{*} \\
(0.086)\end{array}$ \\
\hline (6) Income $^{2}-($ VCF0114*VCF0114) & $\begin{array}{l}-0.020 \\
(0.017)\end{array}$ & $\begin{array}{l}-0.031^{*} \\
(0.017)\end{array}$ \\
\hline (7) South - (VCF0113) & $\begin{array}{c}0.115 \\
(0.090)\end{array}$ & $\begin{array}{l}-0.137 \\
(0.103)\end{array}$ \\
\hline (8) Northeast - (VCF0112) & $\begin{array}{c}-0.01 \\
(0.107)\end{array}$ & $\begin{array}{c}0.088 \\
(0.116)\end{array}$ \\
\hline (9) West - (VCF0112) & $\begin{array}{c}0.036 \\
(0.099)\end{array}$ & $\begin{array}{c}0.061 \\
(0.108)\end{array}$ \\
\hline (10) Protestant - (VCF0128) & $\begin{array}{l}0.098 \\
(0.111)\end{array}$ & $\begin{array}{c}-0.280^{* *} \\
(0.119)\end{array}$ \\
\hline (11) Catholic - (VCF0128) & $\begin{array}{l}-0.040 \\
(0.120)\end{array}$ & $\begin{array}{l}-0.241^{*} \\
(0.127)\end{array}$ \\
\hline (12) Jewish - (VCF0128) & $\begin{array}{l}-0.270 \\
(0.246)\end{array}$ & $\begin{array}{l}0.462^{*} \\
(0.255)\end{array}$ \\
\hline (13) Church Attendance - (VCF0130) & $\begin{array}{c}-0.070^{* * *} \\
(0.024)\end{array}$ & $\begin{array}{l}-0.001 \\
(0.027)\end{array}$ \\
\hline (14) Homemaker - (VCF0116) & $\begin{array}{l}-0.150 \\
(0.130)\end{array}$ & $\begin{array}{l}-0.229 \\
(0.155)\end{array}$ \\
\hline (15) Homeownership - (VCF0146) & $\begin{array}{l}0.159^{* *} \\
(0.078)\end{array}$ & $\begin{array}{c}0.070 \\
(0.090)\end{array}$ \\
\hline (16) Union - (VCF0127) & $\begin{array}{l}-0.120 \\
(0.102\end{array}$ & $\begin{array}{c}0.167 \\
(0.105)\end{array}$ \\
\hline (17) Marital Status - (VCF0147) & $\begin{array}{l}-0.020 \\
(0.022\end{array}$ & $\begin{array}{c}0.080^{* * *} \\
(0.028)\end{array}$ \\
\hline $\begin{array}{l}\text { (18) Political Knowledge (Pre) - } \\
(\text { VCF0050a) }\end{array}$ & $\begin{array}{l}-0.090^{* *} \\
(0.037)\end{array}$ & $\begin{array}{l}-0.040 \\
(0.028)\end{array}$ \\
\hline $\begin{array}{l}\text { (19) Political Knowledge (Post) - } \\
\text { (VCF0050b) }\end{array}$ & $\begin{array}{l}-0.010 \\
(0.025)\end{array}$ & $\begin{array}{c}0.019 \\
(0.027)\end{array}$ \\
\hline (0) Year Dummy & $\begin{array}{l}-0.420 \\
(0.291) \\
\end{array}$ & $\begin{array}{c}-0.616^{* *} \\
(0.304) \\
\end{array}$ \\
\hline Chow Forecast test & $\log 1$ & 0.097 \\
\hline
\end{tabular}

Note: See Table I. VCF9045 is a dummy variable which takes a value of unity if the respondent indicated that the United States Weaker position today than a year ago and zero otherwise. 
Table III: Should Military Spending Be Increased?

\begin{tabular}{|c|c|c|}
\hline \multirow{2}{*}{$\begin{array}{l}\text { Dependent Variable: Increase Military - } \\
\text { (VCF0843) }\end{array}$} & \multicolumn{2}{|c|}{ Year } \\
\hline & 2000 & 2004 \\
\hline (1) Middle age - (VCF0101) & $\begin{array}{l}-0.080 \\
(0.070)\end{array}$ & $\begin{array}{l}-0.064 \\
0.079)\end{array}$ \\
\hline (2) Gender - (VCF0104) & $\begin{array}{c}0.211^{* * *} \\
(0.073)\end{array}$ & $\begin{array}{c}0.354^{* * *} \\
(0.080)\end{array}$ \\
\hline (3) Race - (VCF0106) & $\begin{array}{c}0.071 \\
(0.084)\end{array}$ & $\begin{array}{c}0.248^{* * *} \\
(0.087)\end{array}$ \\
\hline (4) Education - (VCF0110) & $\begin{array}{c}-0.150^{* * *} \\
(0.044)\end{array}$ & $\begin{array}{c}-0.125^{* * *} \\
(0.050)\end{array}$ \\
\hline (5) Income - (VCF0114) & $\begin{array}{l}-0.131^{*} \\
(0.075)\end{array}$ & $\begin{array}{c}0.020 \\
(0.086)\end{array}$ \\
\hline (6) Income $^{2}-($ VCF0114*VCF0114) & $\begin{array}{l}0.039^{* *} \\
(0.016)\end{array}$ & $\begin{array}{l}0.009 \\
(0.017)\end{array}$ \\
\hline (7) South - (VCF0113) & $\begin{array}{c}0.037 \\
(0.090)\end{array}$ & $\begin{array}{c}0.012 \\
(0.101)\end{array}$ \\
\hline (8) Northeast - (VCF0112) & $\begin{array}{l}-0.070 \\
(0.108)\end{array}$ & $\begin{array}{l}-0.208^{*} \\
(0.115)\end{array}$ \\
\hline (9) West - (VCF0112) & $\begin{array}{l}-0.100 \\
(0.101)\end{array}$ & $\begin{array}{l}-0.052 \\
(0.110)\end{array}$ \\
\hline (10) Protestant - (VCF0128) & $\begin{array}{l}0.010 \\
(0.111)\end{array}$ & $\begin{array}{l}0.166 \\
(0.119)\end{array}$ \\
\hline (11) Catholic - (VCF0128) & $\begin{array}{c}0.084 \\
(0.120)\end{array}$ & $\begin{array}{c}0.193 \\
(0.128)\end{array}$ \\
\hline (12) Jewish - (VCF0128) & $\begin{array}{c}-0.04 \\
(0.236)\end{array}$ & $\begin{array}{l}-0.311 \\
(0.244)\end{array}$ \\
\hline (13) Church Attendance - (VCF0130) & $\begin{array}{l}-0.050^{* *} \\
(0.024)\end{array}$ & $\begin{array}{c}0.001 \\
(0.026)\end{array}$ \\
\hline (14) Homemaker - (VCF0116) & $\begin{array}{l}-0.050 \\
(0.132)\end{array}$ & $\begin{array}{c}0.159 \\
(0.153)\end{array}$ \\
\hline (15) Homeownership - (VCF0146) & $\begin{array}{l}-0.06 \\
(0.078)\end{array}$ & $\begin{array}{c}0.071 \\
(0.090)\end{array}$ \\
\hline (16) Union - (VCF0127) & $\begin{array}{c}0.07 \\
(0.100)\end{array}$ & $\begin{array}{l}-0.102 \\
(0.102)\end{array}$ \\
\hline (17) Marital Status - (VCF0147) & $\begin{array}{l}-0.010 \\
(0.023)\end{array}$ & $\begin{array}{l}-0.020 \\
(0.028)\end{array}$ \\
\hline $\begin{array}{l}\text { (18) Political Knowledge (Pre) - } \\
\text { (VCF0050a) }\end{array}$ & $\begin{array}{c}-0.137^{* * *} \\
(0.035)\end{array}$ & $\begin{array}{c}-0.093^{* * *} \\
(0.028)\end{array}$ \\
\hline $\begin{array}{l}\text { (19) Political Knowledge (Post) - } \\
\text { (VCF0050b) }\end{array}$ & $\begin{array}{c}0.018 \\
(0.025)\end{array}$ & $\begin{array}{l}-0.007 \\
(0.028)\end{array}$ \\
\hline (0) Year Dummy & $\begin{array}{c}0.187 \\
(0.280) \\
\end{array}$ & $\begin{array}{c}0.007 \\
(0.302) \\
\end{array}$ \\
\hline Chow Forecast test & $\log l i$ & 70.549 \\
\hline
\end{tabular}

Note: See Table I. VCF0843 is a dummy variable which takes a value of unity if the respondent indicated that military spending should be increased and zero otherwise. 
Table IV: Should Welfare Spending Be Decreased?

\begin{tabular}{|c|c|c|}
\hline \multirow{2}{*}{$\begin{array}{l}\text { Dependent Variable: Increase Welfare - } \\
\text { (VCF0894) }\end{array}$} & \multicolumn{2}{|c|}{ Year } \\
\hline & 2000 & 2004 \\
\hline (1) Middle age - (VCF0101) & $\begin{array}{c}0.197^{* * *} \\
(0.065)\end{array}$ & $\begin{array}{c}0.076 \\
(0.083)\end{array}$ \\
\hline (2) Gender - (VCF0104) & $\begin{array}{c}0.053 \\
(0.068)\end{array}$ & $\begin{array}{l}0.139^{*} \\
(0.083)\end{array}$ \\
\hline (3) Race - (VCF0106) & $\begin{array}{c}0.234^{* * *} \\
(0.079)\end{array}$ & $\begin{array}{l}0.155^{*} \\
(0.092)\end{array}$ \\
\hline (4) Education - (VCF0110) & $\begin{array}{l}-0.050 \\
(0.041)\end{array}$ & $\begin{array}{l}-0.086^{*} \\
(0.051)\end{array}$ \\
\hline (5) Income - (VCF0114) & $\begin{array}{l}-0.030 \\
(0.072)\end{array}$ & $\begin{array}{c}0.055 \\
(0.090)\end{array}$ \\
\hline (6) Income $^{2}-($ VCF0114*VCF0114) & $\begin{array}{c}0.017 \\
(0.015)\end{array}$ & $\begin{array}{l}-0.004 \\
(0.018)\end{array}$ \\
\hline (7) South - (VCF0113) & $\begin{array}{l}-0.030 \\
(0.084)\end{array}$ & $\begin{array}{l}-0.004 \\
(0.105)\end{array}$ \\
\hline (8) Northeast - (VCF0112) & $\begin{array}{c}-0.410^{* * *} \\
(0.102)\end{array}$ & $\begin{array}{c}0.028 \\
(0.120)\end{array}$ \\
\hline (9) West - (VCF0112) & $\begin{array}{l}-0.080 \\
(0.093)\end{array}$ & $\begin{array}{c}0.049 \\
(0.113)\end{array}$ \\
\hline (10) Protestant - (VCF0128) & $\begin{array}{c}0.003 \\
(0.102)\end{array}$ & $\begin{array}{c}0.093 \\
(0.123)\end{array}$ \\
\hline (11) Catholic - (VCF0128) & $\begin{array}{l}0.046 \\
(0.110)\end{array}$ & $\begin{array}{c}0.034 \\
(0.131)\end{array}$ \\
\hline (12) Jewish - (VCF0128) & $\begin{array}{l}-0.050 \\
(0.219)\end{array}$ & $\begin{array}{l}-0.262 \\
(0.262)\end{array}$ \\
\hline (13) Church Attendance - (VCF0130) & $\begin{array}{l}-0.030 \\
(0.022)\end{array}$ & $\begin{array}{l}-0.019 \\
(0.027)\end{array}$ \\
\hline (14) Homemaker - (VCF0116) & $\begin{array}{l}-0.130 \\
(0.124)\end{array}$ & $\begin{array}{l}-0.206 \\
(0.165)\end{array}$ \\
\hline (15) Homeownership - (VCF0146) & $\begin{array}{c}0.096 \\
(0.073)\end{array}$ & $\begin{array}{c}0.110 \\
(0.095)\end{array}$ \\
\hline (16) Union - (VCF0127) & $\begin{array}{l}0.008 \\
(0.094)\end{array}$ & $\begin{array}{l}-0.086 \\
(0.107)\end{array}$ \\
\hline (17) Marital Status - (VCF0147) & $\begin{array}{l}-0.010 \\
(0.021)\end{array}$ & $\begin{array}{c}-0.061^{* *} \\
(0.030)\end{array}$ \\
\hline $\begin{array}{l}\text { (18) Political Knowledge (Pre) - } \\
\text { (VCF0050a) }\end{array}$ & $\begin{array}{l}-0.020 \\
(0.033)\end{array}$ & $\begin{array}{l}-0.006 \\
(0.028)\end{array}$ \\
\hline $\begin{array}{l}\text { (19) Political Knowledge (Post) - } \\
\text { (VCF0050b) }\end{array}$ & $\begin{array}{l}-0.020 \\
(0.024)\end{array}$ & $\begin{array}{l}-0.028 \\
(0.027)\end{array}$ \\
\hline (0) Year Dummy & $\begin{array}{l}-0.230 \\
(0.270) \\
\end{array}$ & $\begin{array}{l}-0.383 \\
(0.313) \\
\end{array}$ \\
\hline Chow Forecast test & $\overline{\log l i}$ & 2.667 \\
\hline
\end{tabular}

Note: See Table I. VCF0894 is a dummy variable which takes a value of unity if the respondent indicated that welfare payments should be Reduced or cut altogether and zero otherwise. 
Table V: Should public education spending be decreased?

\begin{tabular}{|c|c|c|}
\hline \multirow{2}{*}{$\begin{array}{l}\text { Dependent Variable: Increase Education - } \\
\text { (VCF0890) }\end{array}$} & \multicolumn{2}{|c|}{ Year } \\
\hline & 2000 & 2004 \\
\hline (1) Middle age - (VCF0101) & $\begin{array}{l}-0.025 \\
(0.106)\end{array}$ & $\begin{array}{c}0.117 \\
(0.145)\end{array}$ \\
\hline (2) Gender - (VCF0104) & $\begin{array}{l}0.258^{* *} \\
(0.111)\end{array}$ & $\begin{array}{l}0.317^{* *} \\
(0.151)\end{array}$ \\
\hline (3) Race - (VCF0106) & $\begin{array}{c}0.444^{* * *} \\
(0.158)\end{array}$ & $\begin{array}{l}0.832^{* * *} \\
(0.241)\end{array}$ \\
\hline (4) Education - (VCF0110) & $\begin{array}{l}0.131^{* *} \\
(0.063)\end{array}$ & $\begin{array}{c}0.038 \\
(0.098)\end{array}$ \\
\hline (5) Income - (VCF0114) & $\begin{array}{l}-0.240^{* * *} \\
(0.111)\end{array}$ & $\begin{array}{l}-0.225 \\
(0.152)\end{array}$ \\
\hline (6) Income $^{2}-($ VCF0114*VCF0114) & $\begin{array}{l}0.044^{*} \\
(0.025)\end{array}$ & $\begin{array}{l}0.050^{*} \\
(0.029)\end{array}$ \\
\hline (7) South - (VCF0113) & $\begin{array}{c}0.086 \\
(0.137)\end{array}$ & $\begin{array}{l}-0.137 \\
(0.182)\end{array}$ \\
\hline (8) Northeast - (VCF0112) & $\begin{array}{l}-0.110 \\
(0.168)\end{array}$ & $\begin{array}{l}0.055 \\
(0.215)\end{array}$ \\
\hline (9) West - (VCF0112) & $\begin{array}{l}-0.010 \\
(0.152)\end{array}$ & $\begin{array}{c}0.186 \\
(0.190)\end{array}$ \\
\hline (10) Protestant - (VCF0128) & $\begin{array}{l}-0.230 \\
(0.163)\end{array}$ & $\begin{array}{l}0.096 \\
(0.238)\end{array}$ \\
\hline (11) Catholic - (VCF0128) & $\begin{array}{l}-0.220 \\
(0.176)\end{array}$ & $\begin{array}{l}-0.005 \\
(0.260)\end{array}$ \\
\hline (12) Jewish - (VCF0128) & $\begin{array}{l}-0.780^{*} \\
(0.420)\end{array}$ & $\begin{array}{l}-0.483 \\
(0.487)\end{array}$ \\
\hline (13) Church Attendance - (VCF0130) & $\begin{array}{l}-0.050 \\
(0.039)\end{array}$ & $\begin{array}{c}-0.118^{* *} \\
(0.050)\end{array}$ \\
\hline (14) Homemaker - (VCF0116) & $\begin{array}{l}-0.120 \\
(0.223)\end{array}$ & $\begin{array}{l}0.112 \\
(0.266)\end{array}$ \\
\hline (15) Homeownership - (VCF0146) & $\begin{array}{c}0.146 \\
(0.127)\end{array}$ & $\begin{array}{l}0.353^{*} \\
(0.207)\end{array}$ \\
\hline (16) Union - (VCF0127) & $\begin{array}{l}-0.210 \\
(0.171)\end{array}$ & $\begin{array}{l}-0.475^{* *} \\
(0.223)\end{array}$ \\
\hline (17) Marital Status - (VCF0147) & $\begin{array}{l}-0.060 \\
(0.040)\end{array}$ & $\begin{array}{l}0.023 \\
(0.054)\end{array}$ \\
\hline $\begin{array}{l}\text { (18) Political Knowledge (Pre) - } \\
\text { (VCF0050a) }\end{array}$ & $\begin{array}{l}-0.060 \\
(0.053)\end{array}$ & $\begin{array}{l}-0.087 \\
(0.075)\end{array}$ \\
\hline $\begin{array}{l}\text { (19) Political Knowledge (Post) - } \\
\text { (VCF0050b) }\end{array}$ & $\begin{array}{c}0.006 \\
(0.041)\end{array}$ & $\begin{array}{c}-0.134^{* *} \\
(0.061)\end{array}$ \\
\hline (0) Year Dummy & $\begin{array}{l}-1.740 * * * \\
(0.368)\end{array}$ & $\begin{array}{c}-2.099^{* * *} \\
(0.585)\end{array}$ \\
\hline Chow Forecast test & $\log l i$ & 51.854 \\
\hline
\end{tabular}

Note: See Table I. VCF0890 is a dummy variable which takes a value of unity if the respondent indicated that funds spent on public should be Decreased or cut altogether and zero otherwise. 
Table VI: By Law, When Should Abortion Be Allowed?

\begin{tabular}{|c|c|c|}
\hline \multirow{2}{*}{$\begin{array}{c}\text { Dependent Variable: Abortion - } \\
\text { (VCF0838) }\end{array}$} & \multicolumn{2}{|c|}{ Year } \\
\hline & 2000 & 2004 \\
\hline (1) Middle age - (VCF0101) & $\begin{array}{c}0.227^{* * *} \\
(0.068)\end{array}$ & $\begin{array}{l}0.196^{* *} \\
(0.085)\end{array}$ \\
\hline (2) Gender - (VCF0104) & $\begin{array}{c}-0.280^{* * *} \\
(0.071)\end{array}$ & $\begin{array}{c}-0.194^{* *} \\
0.087)\end{array}$ \\
\hline (3) Race - (VCF0106) & $\begin{array}{c}0.001 \\
(0.083)\end{array}$ & $\begin{array}{c}0.049 \\
(0.095)\end{array}$ \\
\hline (4) Education - (VCF0110) & $\begin{array}{c}0.227^{* * *} \\
(0.044)\end{array}$ & $\begin{array}{c}0.199^{* * *} \\
(0.056)\end{array}$ \\
\hline (5) Income - (VCF0114) & $\begin{array}{l}-0.150^{* *} \\
(0.075)\end{array}$ & $\begin{array}{c}0.097 \\
(0.098)\end{array}$ \\
\hline (6) Income $^{2}-\left(V C F 0114^{*} V C F 0114\right)$ & $\begin{array}{l}0.040^{* *} \\
(0.016)\end{array}$ & $\begin{array}{l}-0.003 \\
(0.019)\end{array}$ \\
\hline (7) South - (VCF0113) & $\begin{array}{l}0.225^{* *} \\
(0.090)\end{array}$ & $\begin{array}{c}0.043 \\
(0.116)\end{array}$ \\
\hline (8) Northeast - (VCF0112) & $\begin{array}{l}0.383^{* *} \\
(0.106)\end{array}$ & $\begin{array}{c}0.312^{* * *} \\
(0.126)\end{array}$ \\
\hline (9) West - (VCF0112) & $\begin{array}{c}0.428^{* * *} \\
(0.097)\end{array}$ & $\begin{array}{c}0.408^{* * *} \\
(0.116)\end{array}$ \\
\hline (10) Protestant - (VCF0128) & $\begin{array}{c}0.033 \\
(0.104)\end{array}$ & $\begin{array}{l}-0.163 \\
(0.121)\end{array}$ \\
\hline (11) Catholic - (VCF0128) & $\begin{array}{c}0.015 \\
(0.112)\end{array}$ & $\begin{array}{l}-0.209 \\
(0.132)\end{array}$ \\
\hline (12) Jewish - (VCF0128) & $\begin{array}{l}0.580^{* *} \\
(0.230)\end{array}$ & $\begin{array}{l}0.499^{* *} \\
(0.245)\end{array}$ \\
\hline (13) Church Attendance - (VCF0130) & $\begin{array}{c}0.284 \\
(0.026)\end{array}$ & $\begin{array}{l}0.193 \\
(0.029)\end{array}$ \\
\hline (14) Homemaker - (VCF0116) & $\begin{array}{l}-0.250^{*} \\
(0.138)\end{array}$ & $\begin{array}{c}-0.497^{* * *} \\
(0.180)\end{array}$ \\
\hline (15) Homeownership - (VCF0146) & $\begin{array}{l}-0.040 \\
(0.076)\end{array}$ & $\begin{array}{l}-0.012 \\
(0.098)\end{array}$ \\
\hline (16) Union - (VCF0127) & $\begin{array}{c}0.022 \\
(0.100)\end{array}$ & $\begin{array}{l}-0.110 \\
(0.114)\end{array}$ \\
\hline (17) Marital Status - (VCF0147) & $\begin{array}{l}0.058^{* * *} \\
(0.023)\end{array}$ & $\begin{array}{c}0.018 \\
(0.030)\end{array}$ \\
\hline $\begin{array}{l}\text { (18) Political Knowledge (Pre) - } \\
\text { (VCF0050a) }\end{array}$ & $\begin{array}{l}-0.030 \\
(0.035)\end{array}$ & $\begin{array}{l}-0.086^{* *} \\
(0.036)\end{array}$ \\
\hline $\begin{array}{l}\text { (19) Political Knowledge (Post) - } \\
\text { (VCF0050b) }\end{array}$ & $\begin{array}{c}-0.050^{* *} \\
(0.024)\end{array}$ & $\begin{array}{l}0.182^{* *} \\
(0.031)\end{array}$ \\
\hline (0) Year Dummy & $\begin{array}{l}-1.870^{* * *} \\
(0.287)\end{array}$ & $\begin{array}{c}-2.163^{* * *} \\
(0.352)\end{array}$ \\
\hline Chow Forecast test & Log li & 03.937 \\
\hline
\end{tabular}

Note: See Table I. VCF0838 is a dummy variable which takes a value of unity if the respondent indicated that abortion should under ALL circumstance be allowed and zero otherwise. 
Table VII: Support of Affirmative Action?

\begin{tabular}{|c|c|c|}
\hline \multirow{2}{*}{$\begin{array}{l}\text { Dependent Variable: Affirmative Action - } \\
\text { (VCF9013) }\end{array}$} & \multicolumn{2}{|c|}{ Year } \\
\hline & 2000 & 2004 \\
\hline (1) Middle age - (VCF0101) & $\begin{array}{c}0.045 \\
(0.084)\end{array}$ & $\begin{array}{l}0.225^{* *} \\
(0.105)\end{array}$ \\
\hline (2)Gender - (VCF0104) & $\begin{array}{c}0.040 \\
(0.086)\end{array}$ & $\begin{array}{c}0.011 \\
(0.102)\end{array}$ \\
\hline (3) Race - (VCF0106) & $\begin{array}{l}0.833^{* * *} \\
(0.088)\end{array}$ & $\begin{array}{c}0.695^{* * *} \\
(0.102)\end{array}$ \\
\hline (4) Education - (VCF0110) & $\begin{array}{c}0.049 \\
(0.054)\end{array}$ & $\begin{array}{l}-0.078 \\
(0.065)\end{array}$ \\
\hline (5) Income - (VCF0114) & $\begin{array}{l}0.157^{*} \\
(0.088)\end{array}$ & $\begin{array}{c}0.001 \\
(0.107)\end{array}$ \\
\hline (6) Income $^{2}-($ VCF0114*VCF0114) & $\begin{array}{l}-0.010 \\
(0.02)\end{array}$ & $\begin{array}{c}0.001 \\
(0.021)\end{array}$ \\
\hline (7) South - (VCF0113) & $\begin{array}{l}-0.100 \\
(0.107)\end{array}$ & $\begin{array}{l}-0.203 \\
(0.126)\end{array}$ \\
\hline (8) Northeast - (VCF0112) & $\begin{array}{l}0.147 \\
(0.139)\end{array}$ & $\begin{array}{c}0.130 \\
(0.152)\end{array}$ \\
\hline (9) West - (VCF0112) & $\begin{array}{c}0.195 \\
(0.131)\end{array}$ & $\begin{array}{c}0.050 \\
(0.141)\end{array}$ \\
\hline (10) Protestant - (VCF0128) & $\begin{array}{l}0.098 \\
(0.128)\end{array}$ & $\begin{array}{c}0.494^{* * *} \\
(0.142)\end{array}$ \\
\hline (11) Catholic - (VCF0128) & $\begin{array}{c}0.225 \\
(0.144)\end{array}$ & $\begin{array}{c}0.413^{* * *} \\
(0.158)\end{array}$ \\
\hline (12) Jewish - (VCF0128) & $\begin{array}{c}0.217 \\
(0.332)\end{array}$ & $\begin{array}{c}0.236 \\
(0.309)\end{array}$ \\
\hline (13) Church Attendance - (VCF0130) & $\begin{array}{l}-0.010 \\
(0.028)\end{array}$ & $\begin{array}{c}0.011 \\
(0.033)\end{array}$ \\
\hline (14) Homemaker - (VCF0116) & $\begin{array}{l}0.205 \\
(0.159)\end{array}$ & $\begin{array}{l}-0.012 \\
(0.194)\end{array}$ \\
\hline (15) Homeownership - (VCF0146) & $\begin{array}{l}0.037 \\
(0.091)\end{array}$ & $\begin{array}{c}0.138 \\
(0.108)\end{array}$ \\
\hline (16) Union - (VCF0127) & $\begin{array}{l}-0.010 \\
(0.129)\end{array}$ & $\begin{array}{c}-0.289^{* *} \\
(0.127)\end{array}$ \\
\hline (17) Marital Status - (VCF0147) & $\begin{array}{l}-0.040^{*} \\
(0.026)\end{array}$ & $\begin{array}{c}-0.070^{* *} \\
(0.034)\end{array}$ \\
\hline $\begin{array}{l}\text { (18) Political Knowledge (Pre) - } \\
\text { (VCF0050a) }\end{array}$ & $\begin{array}{l}-0.060 \\
(0.045)\end{array}$ & $\begin{array}{l}0.0648 \\
(0.037)\end{array}$ \\
\hline $\begin{array}{l}\text { (19) Political Knowledge (Post) - } \\
\text { (VCF0050b) }\end{array}$ & $\begin{array}{c}0.029 \\
(0.030)\end{array}$ & $\begin{array}{c}-0.149^{* * *} \\
(0.031)\end{array}$ \\
\hline (0) Year Dummy & $\begin{array}{c}0.152 \\
(0.345)\end{array}$ & $\begin{array}{l}0.673^{*} \\
(0.364)\end{array}$ \\
\hline Chow Forecast test & $\overline{\log 1}$ & 45.707 \\
\hline
\end{tabular}

Note: See Table I. VCF0867 is a dummy variable which takes a value of unity if the respondent indicated that he/she was NOT in favor of affirmative action and zero otherwise. 